\title{
Perpustakahn Anak dengan Pendekatan Psikologi ArsitekTUR Di SURAKarta
}

\author{
Iyud Ditta Oktora, MDE Purnomo, Ana Hardiana \\ Program Studi Arsitektur \\ Jurusan Arsitektur Fakultas Teknik \\ Universitas Sebelas Maret Surakarta \\ Email : iyud89@hotmail.com
}

\begin{abstract}
The existance of children library in Surakarta could become a supporting facility for formal education which can increase children interest in reading, and support Surakarta Goverment efforts on increasing public interest in reading since early cildhood. The purpose of this planning is to obtain a design of children library as a means to improve Surakarta children's interest in reading by using architectural psychology as a design approach. The issue that arises is how to apply the principles of architectural psychology in the children library design. In this planning, studies are done to determine principles of psychological architecture for children library in Surakarta which give the best influence, psychologically, towards children as the main users of this building.The result obtained is a design of children library that adapts the characteristics of children by applying the principles of architectural psychology in building's interior and exterior, creating a children library with interesting, fun, and comfortable atmosphere.
\end{abstract}

Keywords: Children Library, Architectural Psychology

\section{PENDAHULUAN}

Demi mewujudkan tujuan dan sasaran seperti tercantum dalam Rencana Pengembangan Jangka Menengah (RPJM) Daerah Kota Surakarta tahun 2010-2030 mengenai penyelenggaraan fasilitas pendidikan yang ramah anak dan peningkatan akses pendidikan anak usia dini, Pemerintah Kota Surakarta berusaha menumbuhkan minat membaca pada masyarakat melalui berbagai kegiatan. Salah satunya adalah Pesta Buku Solo 2013 yang diadakan dalam rangka memperingati Hari Kunjung Perpustakaan tahun 2013. Tujuan diadakannya kegiatan ini adalah memasyarakatkan buku sebagai pembentukan karakter generasi penerus bangsa serta menumbuhkan minat baca pada masyarakat.

Usaha Pemerintah Kota Surakarta dalam menumbuhkan minat baca tersebut belum didukung oleh fasilitas perpustakaan yang memadai. Oleh karena itu diperlukan adanya suatu wadah yang mampu menampung kegiatan penyaluran minat baca di Surakarta, salah satunya berupa perpustakaan anak.
Perpustakaan anak menjadi salah satu fasilitas penunjang pendidikan formal dan nonformal yang sudah ada. Keberadaan perpustakaan dapat menjadi sebuah sarana untuk memperkaya pengetahuan diri dan juga sebagai tempat rekreasi intelektual melalui membaca.

Dalam perancangan perpustakaan anak, salah satu hal yang penting adalah aspek pengguna yaitu anak. Anak pada jenjang usia tertentu memiliki karakteristik yang berbeda, sehingga desain bangunan memperhatikan dan menyesuaikan dengan karakter anak. Salah satu cara untuk mewujudkan hal tersebut adalah dengan mengaplikasikan prinsip-prinsip Psikologi Arsitektur pada bangunan.

\section{METODE}

Prinsip Psikologi Arsitektur pada bangunan Perpustakaan Anak diaplikasikan pada poin-poin utama berikut ini:

1. Konsep Ruang

Unsur-unsur Psikologi Arsitektur diaplikasikan dalam Perpustakaan Anak untuk menciptakan suasana ruang yang 
sesuai dengan kelompok ruang dan karakteristik pengguna.

2. Bentuk dan Tampilan Bangunan

Bentuk dan tampilan Perpustakaan Anak mengaplikasikan prinsip-prinsip Psikologi Arsitektur untuk menciptakan kesan bangunan yang diharapkan.

\section{ANALISIS}

\subsection{Analisis Peruangan}

\subsubsection{Analisis Kebutuhan Ruang}

Analisis kebutuhan ruang bertujuan untuk mengetahui jenis ruang yang dibutuhkan dalam perpustakaan anak. Ruangan-ruangan ini (lihat Tabel 1) diperoleh melalui analisis pelaku beserta kegiatan di dalam perpustakan anak.

Tabel 1.Kebutuhan Ruang

\begin{tabular}{|l|l|l|}
\hline PELAKU & KEGIATAN & PERUANGAN \\
\hline $\begin{array}{l}\text { Pengun- } \\
\text { jung }\end{array}$ & Datang & Hall penerima \\
\cline { 2 - 3 } & $\begin{array}{l}\text { Informasi dan } \\
\text { pendaftaran }\end{array}$ & Area informasi \\
\cline { 2 - 3 } & $\begin{array}{l}\text { Pencarian } \\
\text { literatur }\end{array}$ & R. Koleksi \\
\cline { 2 - 3 } & $\begin{array}{l}\text { Membaca } \\
\text { koleksi }\end{array}$ & R. Baca \\
\cline { 2 - 3 } & Belajar & R. Belajar \\
\cline { 2 - 3 } & $\begin{array}{l}\text { Mendengar } \\
\text { dan melihat } \\
\text { koleksi } \\
\text { pandang } \\
\text { dengar (Audio } \\
\text { Visual) }\end{array}$ & R. Audio Visual \\
\cline { 2 - 3 } & $\begin{array}{l}\text { Menggunakan } \\
\text { komputer }\end{array}$ & R. Komputer \\
\cline { 2 - 3 } & $\begin{array}{l}\text { Mendengarkan } \\
\text { dongeng }\end{array}$ & R. Dongeng \\
\cline { 2 - 3 } & $\begin{array}{l}\text { Mengikuti } \\
\text { seminar }\end{array}$ & R. Seminar \\
\hline Datang & Hall penerima \\
\cline { 2 - 3 } & Bekerja & R. Kerja \\
\cline { 2 - 3 } rapat & R. Rapat \\
\hline Pengelola & Hall penerima \\
\hline Servis & $\begin{array}{l}\text { Datang } \\
\text { bangkar muat }\end{array}$ & Loading Dock \\
\cline { 2 - 3 } & ang & \\
\hline
\end{tabular}

\subsubsection{Analisis Konsep Ruang}

Ruang dalam perpustakaan anak dibagi menjadi beberapa kelompok yang memiliki kemiripan jenis dan sifat kegiatan. Masingmasing kelompok membutuhkan konsep dan suasana ruang yang berbeda yang disesuaikan dengan karakteristik anak sebagai pengguna. Untuk menciptakan suasana ruang yang diinginkan, unsur Psikologi Arsitektur yang dapat diaplikasikan antara lain:

1. Warna. Pertimbangan pemilihan tata warna ruang adalah pengguna, karakter warna, dan skema warna.

2. Skala. Menurut Paul D. Spriegen (dalam Hakim, 2004) perbandingan antara orang berdiri dengan tinggi bangunannya berpengaruh pada perilaku dan psikologis penggunanya. Untuk menentukan skala ruang pada perpustakaan anak digunakan perbandingan antara tinggi rata-rata pengguna dengan tinggi ruang.

3. Tekstur. Pengaplikasian tekstur pada interior perpustakaan anak menggunakan beberapa kombinasi tekstur dengan tujuan memberikan efek ruangan yang berbedabeda. Tekstur yang berbeda diaplikasikan pada pola lantai maupun dinding.

4. Bentuk. Bentuk dibagi menjadi dua yaitu bentuk geometris tegas menyudut dan bentuk yang melengkung. Kombinasi dari dua kualitas bentuk dapat menciptakan kesan dinamis sehingga mampu memberikan pengalaman dalam merasakan ruang.

\subsection{Analisis Pemilihan Tapak}

Pemilihan lokasi tapak dengan kondisi yang mendukung keberadaan perpustakaan anak sangat menentukan prospek bangunan tersebut.

1. Tujuan

Mendapatkan lokasi tapak yang sesuai untuk bangunan perpustakaan anak.

2. Dasar pertimbangan pemilihan tapak perpustakaan menurut Chiara (1990) adalah:

a. Terletak dekat dengan pusat kegiatan masyarakat dan dilalui jalur transportasi umum. Pemilihan tapak untuk perpustakaan anak yang paling efektif adalah dekat dengan area fasilitas pendidikan (Onal, 2012).

b. Lokasi tapak mudah terlihat dari jalan sekitar.

c. Luasan tapak cukup besar untuk melakukan perluasan. 


\subsection{Analisis Tapak}

Pencapaian ke dalam bangunan memiliki akses yang mudah dan memiliki sirkulasi yang aman untuk menstimulus pengunjung masuk dalam area bangunan.

1. Tujuan: menentukan main entrance, side entrance, dan sirkulasi dalam tapak.

2. Dasar Pertimbangan: kemudahan akses, potensi jalan sekitar, arus kendaraan, tingkat keamanan, efektifitas dan efisiensi sirkulasi.

3. Proses analisis

\section{Main Entrance (ME)}

Mudah dilihat dan diakses dari jalan sekitar. Berhubungan langsung dengan jalan utama untuk kemudahan akses kendaraan. Untuk menghindari keruwetan dalam tapak, maka sirkulasi keluar dan masuk kendaraan dipisah.

\section{Side Entrance (SE)}

Diletakkan terpisah dari ME sebagai akses keluar masuk kendaraan servis (lihat Gambar 1).

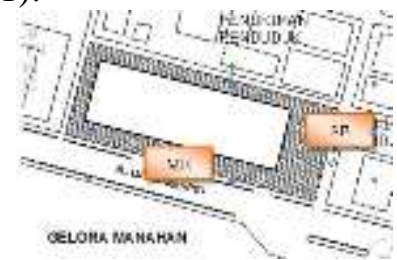

Gambar 1. Pola Pencapaian

\subsection{Analisis Pemintakatan (Zoning)}

Pemintakatan didasarkan pada beberapa pertimbangan, terutama hal yang berhubungan dengan koleksi pustaka.

1. Tujuan: Menentukan mintakat (zoning) berdasarkan jenis kegiatan dan keadaan tapak.

2. Dasar pertimbangan: arah matahari, kebisingan, jenis dan sifat kegiatan.

3. Proses analisis:

a. Analisis arah matahari

Area koleksi membutuhkan ruang yang terhindar dari cahaya dan panas yang dipancarkan matahari untuk menghindari kerusakan pustaka.

b. Analisis kebisingan

Beberapa jenis kegiatan dalam perpustakaan anak membutuhkan situasi yang kondusif dan tenang. Zona kegiatan yang memerlukan ketenangan menyesuaikan dengan kondisi kebisingan lingkungan sekitar.

c. Analisis jenis dan sifat kegiatan

Tabel 2. Jenis dan Sifat Kegiatan

\begin{tabular}{|l|l|}
\hline \multicolumn{1}{|c|}{$\begin{array}{c}\text { MINTA } \\
\text { KAT } \\
\text { ZONING })\end{array}$} & \multicolumn{1}{|c|}{ SIFAT KEGIATAN } \\
\hline $\begin{array}{l}\text { Zona } \\
\text { kegiatan } \\
\text { penerima }\end{array}$ & $\begin{array}{l}\text { Zona yang harus terlihat jelas } \\
\text { dan dekat dengan Main } \\
\text { Entrance. }\end{array}$ \\
\hline $\begin{array}{l}\text { Zona } \\
\text { kegiatan } \\
\text { utama } \\
\text { pelayanan } \\
\text { perpustaka- } \\
\text { an anak }\end{array}$ & $\begin{array}{l}\text { Diperlukan kemudahan } \\
\text { pengawasan dan kemudahan } \\
\text { akses pengunjung. }\end{array}$ \\
\hline $\begin{array}{l}\text { Zona } \\
\text { kegiatan } \\
\text { penunjang }\end{array}$ & $\begin{array}{l}\text { Bersifat umum dan tidak } \\
\text { memerlukan ketenangan. }\end{array}$ \\
\hline $\begin{array}{l}\text { Zona } \\
\text { kegiatan } \\
\text { pengelola }\end{array}$ & $\begin{array}{l}\text { Zona kegiatan pengelola } \\
\text { bersifat terbatas, tidak dapat } \\
\text { diakses pengunjung secara } \\
\text { bebas. }\end{array}$ \\
\hline $\begin{array}{l}\text { Zona } \\
\text { kegiatan } \\
\text { servis }\end{array}$ & $\begin{array}{l}\text { Bersifat pelayanan dan } \\
\text { mendukung kegiatan utama. } \\
\text { Perletakan zona ini berada di } \\
\text { bagian yang tidak terlihat dari } \\
\text { pintu masuk utama. }\end{array}$ \\
\hline
\end{tabular}

Berdasarkan analisis di atas (lihat Tabel 2), diperoleh pemintakatan zona ruang sebagai berikut (lihat Gambar 2).

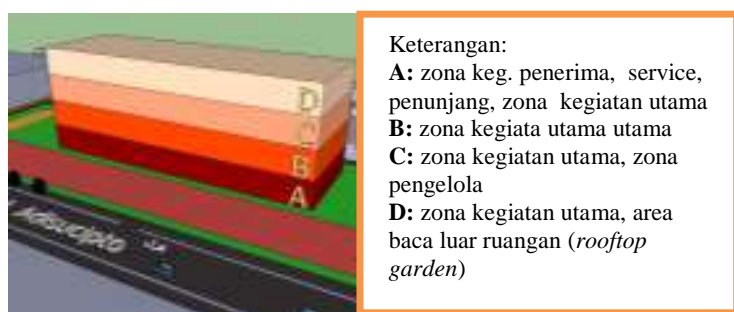

Gambar 2. Pemintakatan Ruang

\subsection{Analisis Bentuk dan Tampilan Bangunan}

\subsubsection{Analisis Bentuk Bangunan}

Bentuk bangunan mempertimbangkan sistem masa dan bermacam-macam gubahan masa, seperti: segiempat, segitiga, dan lingkaran. Hal ini berdasarkan beberapa pertimbangan yaitu:

1. Kesan yang ditampilkan.

2. Kemudahan pengaturan tata letak ruang.

3. Keamanan pengguna.

4. Kemudahan pengolahan sirkulasi.

5. Penyesuaian terhadap fisik di lingkungan tapak dan sekitar tapak.

6. Estetika bentuk.

Berdasarkan faktor pertimbangan di atas, terutama kemudahan dalam pengaturan 
tata letak ruang, maka bentuk dasar bangunan yang dianggap memenuhi kriteria di atas adalah bentuk persegi dan pengembangannya dengan masa tunggal. Pengembangan masa persegi dengan cara menambah atau mengurangi bentuk dasar.

Area tengah yang direncanakan sebagai pintu masuk, menggunakan garis lengkung untuk kesan yang lebih mengundang. Secara psikologis, bentuk lengkung memberikan kesan bangunan menjadi lebih dinamis dan luwes secara visual.

\subsubsection{Analisis Tampilan Bangunan Secara Psikologis}

Perpustakaan anak merupakan fasilitas yang digunakan oleh umum sehingga bangunan memiliki kepribadian terbuka dan bersifat ekstrovert. Pengaplikasian material kaca pada dinding luar dapat memberikan kesan bangunan yang terbuka bagi calon pengunjung.

Desain bangunan memiliki dua jenis karakter yang umum yaitu karakter maskulin dan feminin. Bangunan perpustakaan anak yang direncanakan berusaha menampilkan bangunan dengan karakter maskulin sekaligus feminin. Karakter maskulin bertujuan untuk menampilkan citra bangunan perpustakaan anak yang kuat, kokoh, dan stabil. Karakter tersebut diwujudkan melalui penggunaan bentuk geometris yang tegas. Untuk menyeimbangkan kesan kaku pada karakter maskulin, karakter feminin diterapkan pada bangunan melalui penggunaan bentuk lengkung.

Untuk menghasilkan tampilan bangunan yang mampu menampilkan fungsi bangunan sebagai perpustakaan anak, fasad bangunan mengadaptasi elemen yang berhubungan dengan pustaka berupa buku. Hal ini diwujudkan dengan menggunakan panel-panel berwarna cerah disusun menyerupai buku yang bertumpuk tidak beraturan.

Bagian dengan tangkapan visual paling besar diaplikasikan ornamen berupa pengulangan yang teratur dan atraktif. Untuk menampilkan bangunan sebagai satu kesatuan, pengulangan diaplikasikan pada beberapa sisi bangunan.

\subsection{Analisis Sistem Struktur 3.6.1 Analisis Sub Structure}

1. Tujuan: menentukan struktur pondasi yang tepat sebagai penyangga bangunan.

2. Dasar pertimbangan: ketinggian bangunan, jumlah lantai.

3. Proses analisis:

Sub structure mempertimbangkan beberapa jenis pondasi seperti: batu kali, footplate, sumuran, tiang pancang.

Berdasarkan pertimbangan tersebut jenis struktur yang akan digunakan adalah pondasi footplate.

\subsubsection{Analisis Super Structure}

1. Tujuan: menentukan sistem struktur pada bagian bangunan dinding, kolom, dan balok.

2. Pertimbangan: fungsi ruang, jumlah lantai, beban bangunan.

3. Proses analisis:

Ruang-ruang dalam perpustakaan nantinya akan berisi rak-rak yang berisi buku yang mempunyai beban mati yang besar sehingga struktur penopang pelat lantai harus dapat menanggung beban yang merata di seluruh permukaan lantai perpustakaan. Berdasarkan pertimbangan tersebut, sistem super structure yang akan digunakan adalah sistem rigid frame dengan modul jarak antar kolom enam hingga delapan meter.

\subsubsection{Analisis Upper Structure}

1. Tujuan: menentukan struktur atap yang sesuai.

2. Dasar pertimbangan: estetika bangunan, mendukung fungsi atap sebagai rooftop garden.

3. Proses analisis:

Atap bangunan perpustakaan anak dimanfaatkan untuk area taman baca di luar ruangan sehingga struktur atap harus mampu menampung beban. Berdasarkan pertimbangan tersebut, jenis atap yang akan digunakan adalah struktur beton bertulang.

\section{KESIMPULAN (KONSEP DESAIN)}

Dari hasil analisis serta hasil korelasi dari beberapa data di atas, maka diperoleh hasil berupa desain Perpustakaan Anak di Surakarta sebagai berikut.

Nama : Perpustakaan Anak Surakarta Lokasi : Jl. LU. Adi Sucipto 
Luas Lahan $\quad: \pm 8140 \mathrm{~m}^{2}$

Luas Bangunan : $\pm 13.500 \mathrm{~m}^{2}$

Bangunan perpustakaan anak menggunakan jenis masa tunggal dan bentuk masa persegi yang digabungkan dengan garis lengkung (lihat Gambar 3).

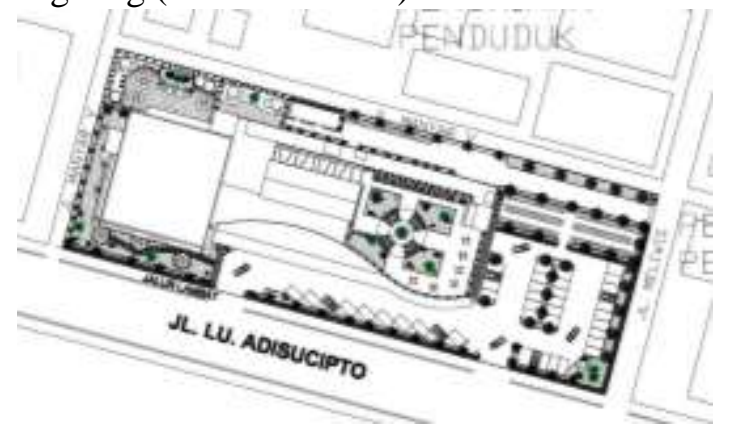

Gambar 3. Situasi

Karakter terbuka dan sifat ekstrovert bangunan diwujudkan dengan penggunaan material kaca pada bagian fasad. Karakter maskulin ditampilkan melalui penggunaan bentuk geometris dengan garis tegas. Karakter feminin ditampilkan melalui bentuk lengkung pada bangunan. Untuk menampilkan bangunan sebagai satu kesatuan, pengulangan dilakukan pada beberapa sisi dengan menggunakan ornamen bentuk dasar yang teratur dan atraktif (lihat Gambar 4).

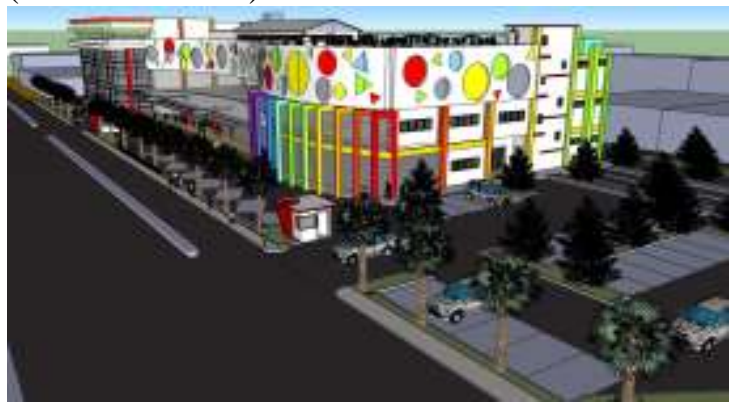

Gambar 4. Gambar Eksterior

Panel-panel menyerupai buku digunakan untuk menghasilkan tampilan bangunan yang berfungsi sebagai perpustakaan anak (lihat Gambar 5).

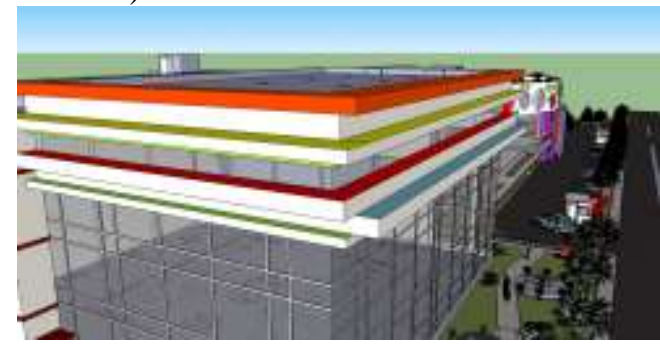

Gambar 5. Detail Panel
Interior ruang baca menyesuaikan karakteristik anak dengan menerapkan unsur Psikologi Arsitektur berupa warna, skala, tekstur, dan bentuk (lihat Gambar 6).

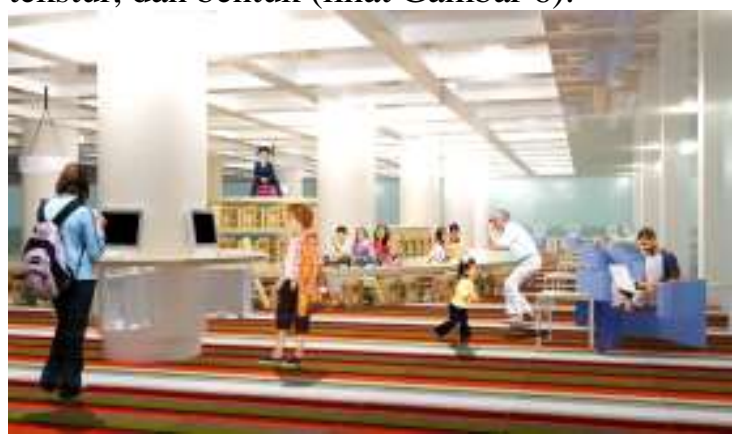

Gambar 6. Interior Ruang Baca

\section{REFERENSI}

Chiara, Joseph De. 1990. Time-Saver Standards for Building Types. McGraw Hill Publishing Company.

Hakim, Rustam. 2004. Komponen Perancangan Arsitektur Lansekap. Jakarta: Bumi Aksara.

Onal, Inci. 2012. Designing Library Space for Children. IFLA Publications Vol.154. Berlin: Walter de Gruyter GmbH \& Co. 